\title{
THE IMPACT OF THE APPLIED EXCHANGE RATE REGIMES ON THE INTERNAL BALANCE OF TRANSITION COUNTRIES
}

\author{
Vlado Vujanić \\ The Republic of Srpska, Ministry of Finance, Bosnia and Herzegovina \\ Vasilj Žarković
}

University of Banja Luka, Faculty of Economics Banja Luka, Bosnia and Herzegovina

Dragan Gligorić

University of Banja Luka, Faculty of Economics Banja Luka, Bosnia and Herzegovina

date of paper receipt:

07.08.2017.

Orginal article date of sending to review:

10.08.2017. date of review receipt:

28.08.2017.

\section{SUMMARY}

One of the key goals of the economic policy makers of every country is to achieve internal and external balance. An unavoidable segment of the analysis concerning the achievement of internal and external balance is certainly the influence of the exchange rate regime applied in a country. European transition countries, despite their similar initial problems and final objectives, applied different exchange rate regimes adapted to the economic circumstances and needs of the country. The paper aims to examine and demonstrate the impact of the applied exchange rate regime on the internal balance of the transition countries. The research encompasses 10 representative transition countries, in the period from 2000-2014. The results of the research, from the aspect of internal balance, confirmed the justification of the application of the floating exchange rate regime in more developed, but not in less-developed, European transition countries. The application of floating exchange rate regimes in less-developed transition countries is associated with a considerably higher average inflation rate, which may be explained by the higher import dependence of lessdeveloped countries and by the consequent transfer of depreciation to price growth.

Key words: transition countries, exchange rate regimes, economic growth, unemployment, inflation

JEL classification code: E31, E52, F41, F43

\section{INTRODUCTION}

Achieving internal and external macroeconomic balance presents the key economic goal of every country. According to the definition by Krugman and Obstfeld (2009), when a country's productive resources are fully employed and its price level is stable, the country is in internal balance. External balance represents a certain target state of the current account towards which economic policy makers aspire, and which may imply a lower deficit, namely, a current account surplus.

The exchange rate regime, as a manner of establishing and managing changes in the exchange rate, influences how and to what extent the monetary authority will control not only the movement of the exchange rate, but also the volume of money and the level of interest rates, and thus how and how much it can affect international flows of goods and capital flows, price stability, production and employment. In that context, 
one of the key assignments of the monetary authorities is to choose an appropriate exchange rate regime, in line with the conditions of the national economy, and in accordance with defined macroeconomic goals. The most common classification of the exchange rate regimes is into fixed and floating regimes, which, as the two basic regime groups, depending on the intervention policy of the monetary authorities in the foreign exchange market, are operationalized in various forms. The IMF exchange rate classification from 1998, based on de facto exchange rate policies, distinguishes eight exchange rate regimes, grouped according to the increasing degree of flexibility: no separate legal tender, currency board arrangements, conventional peg, pegged exchange rates within horizontal bands, crawling pegs, crawling bands, managed floating and independently floating. In order to allow for greater coherence and objectivity and improve transparency, the aforementioned system of the exchange rate regimes was modified in 2009. ${ }^{1}$

Despite similar initial economic problems and ultimate goals, the experience has shown, especially in the period after solving initial transition difficulties, that the choice of exchange rate regimes among European transition countries was significantly different - from independently floating to currency board arrangements, and acceptance of the euro as a common currency. Taking that into consideration, the paper seeks to determine whether the differences in the applied exchange rate regimes, after the period of macroeconomic stabilization, and in circumstances characterized by European transition countries, as countries with mutual similarities, but also their specificities in relation to other transition countries and developing countries as a whole, have led to differences in their macroeconomic performance at a domestic level (output, employment, inflation).

The paper attempts to provide an answer to what extent the applied exchange rate regimes have affected the internal balance of transition countries. The starting premise is that the application of floating regimes in transition countries enables faster achievement of internal balance. The premise is based on the theoretical conception that automatic changes in the nominal exchange rate, which allows the application of floating regimes, weaken the effect of negative external shocks on the national economy, thereby alleviating internal disorders such as decline in production and employment. In floating exchange rates regimes, monetary policy, from the aspect of the use of instruments, is free enough to address the internal issues (price stability, employment, economic growth) and can have a stabilization (countercyclical) role. In the context in which the primary money issue should be linked to the value-creation process in the economy and, relating it mainly to exchange flows, the application of the fixed exchange rate regime, by imposing strict rules for the primary money issue, impedes the achievement of the optimum amount of money in circulation. This may cause the problem of liquidity, the slowdown of the economy, reduction of production and employment, or, on the other hand, it may lead to the inflationary processes.

In addition to the Introduction and Conclusion, the paper consists of four segments. The first part of the paper discusses general experiences in the application of exchange rate regimes in the European transition countries that are on their path to the EU or have become its members. The second segment provides an overview of the main results of the previous empirical studies regarding the impact of the applied exchange rate regimes on internal balance. The third part of the paper describes the methods of research, the used data sources and the samples, while the fourth segment of the paper consists of the empirical part. The Conclusion provides the summary of the key results of the conducted research.

\section{EXPERIENCES IN THE APPLICATION OF EXCHANGE RATE REGIMES IN EUROPEAN TRANSITION COUNTRIES}

The beginning of the transition process has been characterized by the pronounced disorders of internal and external balance ${ }^{2}$ and uncertain circumstances, as well as the need for faster economic development and integration into the regional and global economy. The choice of an adequate

$1 \quad$ See Habermeier, Kokenyne, Veyrune and Anderson (2009).

2 The three-digit inflation rate, which according to the study by Fischer and Sahay (2000) was avoided only in three European transitional countries, best illustrates the extent of economic disturbances 
rate exchange regime was one of the significant dilemmas of the European transition countries in circumstances where internal stabilization (reducing inflation) requires a more stable exchange rate, while external stabilization requires a more competitive and more flexible peg of domestic currency. Given that at the beginning of the transition process, the inflation was the biggest problem and the greatest concern, Fischer and Sahay (2000) note that many European transition countries, which entered the transition process relatively early, such as Poland, the Czech Republic, Hungary, Slovakia, Estonia, Croatia, and Macedonia, have opted for some form of fixed exchange rate in providing support to the disinflation process. ${ }^{3}$ The fixed exchange rate as a nominal "anchor" of the stabilization program should contribute to combating inflation and putting it under control. Countries such as Albania, Bulgaria, Latvia, Lithuania, Romania and Slovenia have targeted a certain monetary aggregate, often insufficiently transparent, in order to stabilize prices, while the exchange rate is fundamentally determined by market forces. Due to the insufficient level of exchange rate reserves necessary to maintain the peg, or due to the belief that, in the circumstances of the increasing openness of national economies, the exchange rate market formation will prevent larger oscillations of economic activity, these countries opted for more flexible exchange rate regimes, mostly for independently floating. However, after a relatively short period, Lithuania, Latvia and Bulgaria, having failed to achieve the expected progress in fighting inflation and putting it under control, were forced to carry out monetary reform and move to the fixed exchange rate regime. Bosnia and Herzegovina, Serbia ${ }^{4}$ and Montenegro are countries where, due to expressed political instability and war events, the transition process was discontinued, with a delay of almost a decade, and was continued with the application of fixed exchange rate regimes. Therefore, in the initial transition phase, given that the inflation was the biggest problem of most European transition countries in creating and establishing a framework of monetary stability, as one of the priorities for the successful implementation of the transition process, the priority was given to a fixed exchange rate regime which as a nominal "anchor" of the monetary, but also the overall macroeconomic, policy was to support the disinflation process.

The experience of many transition countries has confirmed that the fixed exchange rate policy, as part of the anti-inflation strategy, has contributed to macroeconomic stabilization reflected in a relatively rapid reduction of the inflation rate to single digits, creating thus conditions for the improvement of structural reforms. Price stabilization and the continuation of structural reforms were accompanied by the inflow of foreign capital, which in the circumstances of maintaining the nominal exchange rate unchanged created inflationary pressure. This led to the appreciation of the real exchange rate and deterioration in the international competitiveness of the national economy, and consequently to the increased risk of rapid devaluation. The appreciation trend of the real exchange rate, due to the increasing openness of national economies, caused some transition countries to abandon fixed and accept more flexible forms of the exchange rate and monetary policy regime, with a view to stimulating competitiveness of the economy, (Beker, 2010).

On the basis of the studies by Reinhart and Rogoff (2002), and Bubula and Ötker-Robe (2002), and the IMF publication, primarily the report on exchange regimes and restrictions, but also based on my own research, it has been determined that Poland, the Czech Republic, Slovakia, Hungary and Serbia, following the initial macroeconomic stabilization established with the help of a fixed exchange rate and most often under the influence of capital inflows, gradually moved to more flexible forms of exchange rate regimes (horizontal bands, crawling peg and crawling band), in order to finally adopt the regime of managed/independently floating exchange rate. This practically means that the floating exchange rate regimes in these countries are still in use, except in the case of Slovakia, which, at first with the acceptance of the ERM II mechanism, and then the single

3 Fixed regimes: currency board arrangements, explicit and implicit peg, crawling peg with floating margins. Floating regimes: independently (free) and managed floating .

$4 \quad$ Although the monetary authorities of Serbia, after political changes in October 2000, announced the use of a managed floating regime, Beker (2010) finds that the fixed rate regime was applied in conventional form until January 2003. 
currency - the euro, returned to fixed exchange rate regimes.

The European transition countries, which, after the initial macroeconomic stabilization, decided to apply some form of fixed exchange rate regimes, given the state of internal and external balance, include: Estonia, Lithuania, Latvia, Bosnia and Herzegovina, Bulgaria, Montenegro and Croatia. Estonia, Lithuania (until entry into the Eurozone), Bulgaria and Bosnia and Herzegovina apply the currency board arrangements. Before the entry into the Eurozone, Latvia applied conventional fixed peg. Montenegro uses the euro as the official means of payment and, accordingly, a firm fixed regime in the form of official euroisation, while Croatia and Macedonia, by linking their currencies to the euro, apply the classic form of a fixed regime with the possibility of peg adjusting. It can be concluded that countries such as Albania, Romania and Slovenia, both in the initial and in the next stages of the transition process, applied floating exchange rate regimes and/or some form of so-called soft peg (usually in the form of crawling bands), although the exchange rate did not play the role of a nominal "anchor". Unlike Slovenia, which, like Slovakia, first accepted the ERM II mechanism, and then the single currency - the euro, returned to the fixed exchange rate regime, Albania and Romania, today, apply floating exchange rate regimes.

\section{AN OVERVIEW OF PREVIOUS RESEARCH}

Many empirical studies find the connection between fixed exchange rate regime and low inflation. Such is the study conducted by Ghosh, Guide, Ostry and Wolf (1996) on a sample of 145 countries classified into three groups (hard peg, intermediate and floating), on the basis of the official exchange rate regime applied during the $1960-1990$ period. The average annual inflation rate in the countries that applied hard peg was $8 \%, 14 \%$ in countries with intermediate regime and $16 \%$ in countries with floating exchange rate regimes. Differences in average inflation rates are even more pronounced in a group of countries with low per capita income, where the difference between a fixed and a floating regime is almost 10 percentage points. Furthermore, the authors point out that the fixed exchange rate regimes, by increasing confidence in monetary authorities and the national currency, may cause more demand for the domestic currency (the desire to keep the money, not to spend), which will affect not only the lower money circulation speed, but also faster decline in domestic interest rates.

A study carried out by the International Monetary Fund (IMF, 1997), which included developing countries, in the 1975-1996 period, classified in two basic groups of regimes (fixed and floating), showed that the average inflation rate is usually lower 5 to 6 p.p. in countries that applied the fixed exchange rate regimes than in countries with floating exchange rate regimes, with the observation that, especially during the 1990s, these inflation rates converged among themselves.

Using a sample of 154 countries (22 industrial and 132 non-industrial), whose macroeconomic variables were observed in the period after the collapse of the Bretton Woods monetary system, Levy-Yeyati and Sturzenegger (2001) obtain results that also indicate the link between the fixed exchange rate regime and low inflation, but only if the fixed exchange rate regime was applied for five years or more. Countries that apply the fixed exchange rate regime for five years or more have lower inflation rates, but at the expense of slower economic growth. Contrary to that, countries that apply the fixed exchange rate regime for less than five years, in relation to the countries applying a floating exchange rate, achieve lower economic growth rates without having a positive effect on the inflation side.

While studying the link between the exchange rate and inflation regimes, Rogoff, Husain, Mody, Brooks and Oomes (2003), using a sample of 153 countries in the period from 1946-2001, concluded that the advantage of fixed exchange rate regimes over other regimes relates mainly to developing countries with relatively low income. In the group of countries with emerging markets, research results showed the absence of a stronger link between inflation and exchange rate regimes. 
In the group of developed countries, the results indicate that floating regimes are associated with somewhat lower inflation than in countries of the same group that have fixed exchange rate regimes. The advantage of a fixed over floating exchange rate regime in achieving price stability has been demonstrated in a recent study by Gosh, Kureshi and Tsangarides (2011), which included 145 countries (emerging and emerging markets - EMDCs), classified in three groups of de facto regimes (hard peg, intermediate and float), in the 1980-2010 period. It was determined that the average inflation rate in countries with hard peg amounted to 5.8\%, 9.4\% with float, and $11.2 \%$ with intermediate regime. The research concluded that the lower inflation rate is a consequence of the monetary discipline imposed by the fixed exchange rate regimes. The second reason for lower inflation is the "confidence effect" - the greater confidence created by the fixed exchange rate regime reduces inflation for the given money growth rate.

Certain differences in empirical conclusions may be observed in not so extensive literature on the linkage of the exchange rate regime with economic growth, as is the case with inflation. In the aforementioned study, Gosh et al. (1996) note that the highest growth rate of GDP per capita of $2.1 \%$ was achieved in intermediate, followed by float of $1.7 \%$, while in the application of hard peg the lowest growth rate of $1.4 \%$ was recorded. The authors explain differences in economic growth rates by the differences in investment rates and productivity growth. Namely, the investment rates have a declining trend from hard peg - through intermediate-towards float. However, fixed exchange rate regimes are linked to larger investments, but at the same time they are in correlation with slower productivity growth compared to countries with floating regimes. Furthermore, the research at the level of sub-samples led to different conclusions about economic growth. The highest rate of per capita income growth was recorded in countries with fixed exchange rate regimes, in the group of industrially developed countries and high income countries. In the group consisting of medium and low income countries, the highest rate of growth was recorded in countries with floating exchange rate regimes. However, the difference in rates of economic growth between countries using the fixed regime and countries using the floating exchange rate is not significant.

The research of the International Monetary Fund (IMF, 1997) conclude that there is no clear link between the exchange rate regime and the production growth. The research showed that the average real growth rate was higher in countries with floating regimes compared to countries with fixed exchange rate regimes. This is partly a consequence of the inclusion of the fast-growing Asian economy in the group of countries with floating exchange rate. When these countries are excluded, the growth performance between these two groups of regimes does not differ significantly.

Using the IMF's classification of the exchange rate regime, Levy-Yeyati and Sturzenegger (2001), found that the highest average rates of per capita income growth in the 1974-1999 period were achieved by the countries with intermediate regimes, in the amount of $2 \%$, followed by countries with fixed exchange rate of $1.2 \%$, while the lowest rates were recorded by countries with floating regimes of $1 \%$. However, according to the Levy-Yeyati \& Sturzenegger (LYS) regime classification, countries with floating regimes of $1.9 \%$ had the highest average growth rate per capita income.

Rogoff et al. (2003) note that within developing countries, economic growth decreases with increased flexibility of the regime, although the effect is not statistically significant. Consequently, the claim that lower inflation is associated with higher exchange rate rigidity, according to the authors, seems to cause growth reduction. For emerging markets, the link between growth and the exchange rate regime is also uncertain. Contrary to that, developed market economies in floating regimes achieve higher rates of economic growth than those applying fixed exchange rate, without generating inflation. In fact, the results suggest that the rigidity of exchange rate is accompanied by slower growth for developed economies.

De Vita and Kyaw (2011) conducted a study analyzing 70 developing countries in the period from 1981 to 2004 . The study did not establish a significant link between the choice of the exchange rate regime and the economic growth.

In an empirical study of the impact of the exchange rate regime on economic growth, conducted 
for the period of the first decade of the 21st century for Central and Eastern European countries, Ihnatov and Capraru (2012) conclude that countries that had applied more flexible regimes had better growth indicators in relation to countries with fixed regimes.

A recent analysis by Sosvilla-Riveroa and Ramos-Herrera (2014) encompassing 123 countries, reveals that, from the aspect of economic growth, countries with intermediate exchange rate regimes have the best performances, while the countries with floating regimes have the poorest performances. Differences in the impact of the applied exchange rate regime are more pronounced in countries with a lower level of per capita income.

\section{RESEARCH METHODS, DATA AND SAMPLES}

The paper provides a comparison of the different exchange rate regimes according to their impact on the internal balance between two groups of European transition countries - countries that apply a fixed and countries applying the floating exchange rate regime, after a period of macroeconomic stabilization. The grouping of countries according to the exchange rate regimes that were applied by monetary authorities was carried out on the basis of a database prepared by Bubula and ÖtkerRobe (2002) for the 1990-2001 period, and on the basis of the IMF publication - reports on exchange regimes and restrictions. In order to exclude the effect of the so-called low base, to a certain extent with some countries, and in order to get a sufficiently long period characterized by the predominant application of the fixed or floating exchange rate regime, the focus was placed on the period from 2000 to 2014. The analysis encompasses 10 European transition countries that are on their path to the EU or have become its members, namely four countries that during 2000-2014 mainly applied fixed regimes and 6 countries that mainly applied floating exchange rate regimes. In order to appreciate the differences in the level of development that exist between the countries with floating regimes, and to some extent limit the influence of the level of economic development on the results of the research, two samples each with three countries were taken from this group (Table 1).

Table 1. Structure of samples of European transition countries

\begin{tabular}{|l|r|}
\hline $\begin{array}{l}\text { Countries with fixed exchange rate } \\
\text { regimes }\end{array}$ & $\begin{array}{r}\text { Countries with floating exchange } \\
\text { rate regimes }\end{array}$ \\
\hline & Less developed countries \\
\hline Bosnia and Herzegovina & Albania \\
\hline Bulgaria & Romania \\
\hline Estonia & Serbia \\
\hline Latvia & More developed countries \\
\hline & Poland \\
\hline & The Czech Republic \\
\hline
\end{tabular}

Source: Author's presentation

The classification of transition countries with floating exchange rate regimes into less developed and more developed countries requires the empirical analysis of the impact of the applied exchange rate regime on internal balance consisting of two parts. The first part of the empirical analysis includes countries with fixed exchange rate regimes and less developed countries with floating exchange rate regimes. In the second part, the same analysis is done between countries with fixed regimes and more developed countries with floating regimes.

The GDP, the consumer price index and the unemployment rate were taken out of the set of basic 
macroeconomic indicators that point to the state of internal balance of a country. A comparative analysis and an impact assessment of the applied exchange rate regimes on economic growth, (un) employment and price stability, in the period from 2000 to 2014, is carried out between European transition countries with fixed and countries with floating exchange rate regimes, by comparing their long-term average values and their movements with the measure of variability (interval of variation and standard deviation). The examination of the statistical significance of the observed differences in the long-term average values of the observed macroeconomic indicators is done by a two-way Student's t-test for testing the equality of arithmetic means of two basic sets based on two independent samples, for a level of significance of 5\% $(\alpha=0.05)$, using EXCEL Statistical tool.

Data on economic growth rates, inflation rates and unemployment rates, in relative values and annual frequency, on which a descriptive analysis and application of the statistical test are based, are taken from the IMF publication - World Economic Outlook, April 2016, except the data on unemployment rates in $\mathrm{BiH}$, which are taken from the World Bank's statistics.

\section{RESEARCH RESULTS}

\section{Countries with fixed and less developed countries with floating exchange rate regimes}

Contribution of the exchange rate regimes to economic growth

By comparing the movements in annual real GDP growth rates using variables (variation interval and standard deviation), given in Table 2 , it can be noted that their values are more dispersed at the sample level of countries with fixed exchange rate regimes.

Table 2. Difference in GDP growth rates between sample countries with fixed and sample of less developed countries with floating exchange rate regimes

Overview of statistics:

\begin{tabular}{|l|r|r|r|r|r|}
\hline Variable & Observations & Minimum & \multicolumn{1}{|c|}{ Maximum } & Mean & \multicolumn{1}{l|}{ Std. deviation } \\
\hline Fixed regimes & 15 & -8.527 & 8.655 & 3.790 & 4.404 \\
\hline Floating regimes & 15 & -2.276 & 7.693 & 3.877 & 2.948 \\
\hline
\end{tabular}

Results of a two-way Student's t-test for two independent samples:

\begin{tabular}{|l|r|}
\hline Difference & -0.087 \\
\hline $\mathrm{t}$ (Observed value) & -0.064 \\
\hline$|\mathrm{t}|$ (Critical value) & 2.048 \\
\hline $\mathrm{DF}$ & 28 \\
\hline 95\% confidenceinterval on the difference between the means: & $(-2.890)$ to (2.716) \\
\hline $\mathrm{p}$-value (Two-tailed) & 0.950 \\
\hline alpha & 0.05 \\
\hline
\end{tabular}

Source: The result of data analysis using the Excel statistical tool - XLSTAT2016.

However, the obtained data on the average value of the real GDP growth rate, realized in the period from 2000 to 2014, which at the level of the sample of less developed countries with floating regimes is $3.9 \%$, and at the level of the sample of countries with fixed exchange rate regimes is $3.8 \%$, indicate that these are negligible differences. The value of $\mathrm{p}=0.950>\alpha$, obtained by the $\mathrm{t}$-test, also confirms that the observed difference in average values of 0.1 p.p. is statistically negligible. This means that there is no proven existence of a clear link between the applied exchange rate regime and economic growth. 


\section{CONTRIBUTION OF THE EXCHANGE RATE REGIME TO PRICE STABILITY}

Significantly worse dispersion measures (variation interval and standard deviation), achieved at the sample level of less developed countries with floating regimes, shown in Table 3, suggest that the application of these exchange rate regimes, in the long run, is accompanied by a lower degree of price stability compared to fixed exchange rate regimes. In addition, the t-test result $(p=0.011<\alpha)$ confirms that the difference in the average values of the inflation rates, achieved in the period from 2000 to 2014, is statistically significant, namely, that it is related to the differences in the applied exchange rate regimes. This implies that the greater contribution of fixed exchange rate regimes to price stability is proved in this part of the analysis, in comparison with the floating regimes.

Table 3. Difference in inflation rates between sample countries with fixed and sample of less developed countries with floating exchange rate regimes

Overview of statistics:

\begin{tabular}{|l|r|r|r|r|r|}
\hline Variable & Observations & Minimum & Maximum & \multicolumn{1}{l|}{ Mean } & \multicolumn{1}{l|}{ Std. deviation } \\
\hline Fixed regimes & 15 & -0.333 & 11.308 & 3.909 & 2.889 \\
\hline Floating regimes & 15 & 1.594 & 22.853 & 8.441 & 5.771 \\
\hline
\end{tabular}

Results of a two-way Student's t-test for two independent samples:

\begin{tabular}{|l|r|}
\hline Difference & -4.532 \\
\hline$t$ (Observed value) & -2.720 \\
\hline$|t|$ (Critical value) & 2.048 \\
\hline DF & 28 \\
\hline $\begin{array}{l}95 \% \text { confidenceinterval on the difference between the } \\
\text { means: }\end{array}$ & $(-7.945)$ to $(-1.118)$ \\
\hline$p$-value (Two-tailed) & 0.011 \\
\hline alpha & 0.05 \\
\hline
\end{tabular}

Source: The result of data analysis using the Excel statistical tool - XLSTAT2016.

Impact of the exchange rate regime on the unemployment rate

The results of descriptive analysis, given in Table 4, show that the values of annual unemployment rates, realized during 2000-2014, differ to a greater degree among countries at a sample level of countries with fixed regimes compared to the sample of less developed countries with floating exchange rate regimes.

Table 4. Difference in unemployment rates between sample countries with fixed and sample of less developed countries with floating exchange rate regimes

\begin{tabular}{|l|r|r|r|r|r|}
\hline Variable & Observations & Minimum & Maximum & \multicolumn{1}{l|}{ Mean } & \multicolumn{1}{l|}{ Std. deviation } \\
\hline Fixed regimes & 15 & 10.690 & 18.420 & 15.321 & 2.234 \\
\hline Floating regimes & 15 & 11.013 & 15.365 & 13.429 & 1.346 \\
\hline
\end{tabular}


Overview of statistics:

Results of a two-way Student's t-test for two independent samples:

\begin{tabular}{|l|r|}
\hline Difference & 1.892 \\
\hline$t$ (Observed value) & 2.810 \\
\hline$|t|$ (Critical value) & 2.048 \\
\hline DF & 28 \\
\hline $95 \%$ confidence interval on the difference between the means: & $0.513)$ to (3.272) \\
\hline$p$-value (Two-tailed) & 0.009 \\
\hline alpha & 0.05 \\
\hline
\end{tabular}

Source: The result of data analysis using the Excel statistical tool - XLSTAT2016.

With more unfavorable dispersion measures, the sample of countries with fixed exchange rate regimes also has more unfavorable central tendency measures. According to the obtained data, the long-term average unemployment rate at the level of the sample with fixed regimes is $15.3 \%$, and at the level of the sample with floating regimes $13.4 \%$. The $\mathrm{p}$ value of $0.009<a$ obtained by a t-test indicates that there is observed difference in unemployment rates, regardless of the fact that it is relatively small, nevertheless statistically significant. In other words, the results of the test show that differences in unemployment rates are caused by differences in the applied exchange rate regimes.

\section{Countries with fixed and developed countries with floating exchange rate regimes}

Contribution of the exchange rate regime to economic growth

Descriptive statistics of the observed samples relating to the variability measurements (interval of variation and standard deviation), presented in Table 5, show that, at the sample level of more developed countries with floating regime, the annual GDP growth rates, realized in the range of -1.1 to $7.9 \%$, significantly differ from one another, than at the level of the fixed exchange rate regime, where they were realized in the range of $-8.5 \%$ to $8.6 \%$.

Table 5. Difference in GDP growth rates between sample countries with fixed and sample countries with floating exchange rate regimes

Overview of statistics:

\begin{tabular}{|l|l|r|r|r|r|}
\hline Variable & $\begin{array}{l}\text { Observa- } \\
\text { tions }\end{array}$ & Minimum & Maximum & Mean & Std. deviation \\
\hline Fixed regimes & 15 & -8.527 & 8.655 & 3.790 & 4.404 \\
\hline Floating regimes & 15 & -1.104 & 7.855 & 3.397 & 2.444 \\
\hline
\end{tabular}

Results of a two-way Student's t-test for two independent samples:

\begin{tabular}{|l|r|}
\hline Difference & 0.393 \\
\hline$t$ (Observed value) & 0.302 \\
\hline$|t|$ (Critical value) & 2.048 \\
\hline DF & 28 \\
\hline $\begin{array}{l}\text { 95\% confidenceinterval on the difference between the } \\
\text { means: }\end{array}$ & $(-2.271)$ to (3.057) \\
\hline$p$-value (Two-tailed) & 0.765 \\
\hline alpha & 0.05 \\
\hline
\end{tabular}

Source: The result of data analysis using the Excel statistical tool - XLSTAT2016 
However, in the period from 2000 to 2014, at the sample level of countries with fixed regimes, a slightly higher average value of the real GDP growth rate was achieved compared to the sample of the more developed countries with floating exchange rate regimes, namely from $3.8 \%$ towards $3.4 \%$. The Student's t-test result $(\mathrm{p}=0.765>a)$ indicates that the difference in the average values of the real GDP growth rate is not statistically significant. This implies that the different exchange rate regimes have not affected the differences in the GDP growth rates. Therefore, as in the part of the analysis involving transition countries with fixed and less developed countries with floating regimes, there is also no evidence of the existence of a clear link between the exchange rate regime and the economic growth.

\section{CONTRIBUTION OF THE EXCHANGE RATE REGIME TO PRICE STABILITY}

By comparing the movement of annual inflation rates with the measures of variability (interval of variation and standard deviation), given in Table 6, it can be noted that their values (achieved in the range of 0.2 to $8.7 \%$ ) are less dispersed at the sample level of developed countries with floating regimes, than at the level of the sample with fixed exchange rate regimes (realized in the range from -0.3 to $11.3 \%$ ). A lower degree of mutual differentiation of annual inflation rates at the sample level of more developed countries with floating regimes was also followed by their lower longterm average value, which, according to the data obtained, at the level of the sample with floating regimes is $3.3 \%$, and $3.9 \%$ at the sample level with fixed regimes. Although descriptive statistics suggest that, within the more developed transition countries, floating regimes, in the long run, provide a somewhat higher level of price stability than fixed exchange rate regimes, the t-test result ( $\mathrm{p}=0.484$ samples) shows that the difference in the average values of the inflation rate are not statistically significant, namely, from the aspect of the exchange rate regime, the samples behave as if belonging to the same group of transition countries.

Table 6. Difference in inflation rates between sample countries with fixed and sample more developed countries with floating exchange rate regimes

Overview of statistics:

\begin{tabular}{|l|l|r|r|r|r|}
\hline Variable & $\begin{array}{l}\text { Observa- } \\
\text { tions }\end{array}$ & Minimum & Maximum & Mean & Std. deviation \\
\hline Fixed regimes & 15 & -0.333 & 11.308 & 3.909 & 2.889 \\
\hline Fluctuating regimes & 15 & 0.164 & 8.690 & 3.259 & 2.062 \\
\hline
\end{tabular}

Results of a two-way Student's t-test for two independent samples:

\begin{tabular}{|l|r|}
\hline Difference & 0.650 \\
\hline$t$ (Observed value) & 0.710 \\
\hline$|t|$ (Critical value) & 2.048 \\
\hline DF & 28 \\
\hline $95 \%$ confidenceinterval on the difference between the means: & $(-1.227)$ to (2.528) \\
\hline$p$-value (Two-tailed) & 0.484 \\
\hline alpha & 0.05 \\
\hline
\end{tabular}

Source: The result of data analysis using the Excel statistical tool - XLSTAT2016 
IMPACT OF THE EXCHANGE RATE REGIME ON THE UNEMPLOYMENT RATE

The results of the descriptive analysis presented in Table 7 indicate that the sample with floating regime, compared to a sample with the fixed exchange rate regime, has somewhat more unfavorable variability measures, that is, a wider variation interval and a higher standard deviation, but a better parameter of the central tendency, i.e. higher long-term average unemployment rate, namely $11 \%$ to $15.3 \%$. The obtained $\mathrm{p}$ value of $0.0004<\alpha$ confirms that the difference in average unemployment rates of 4.3 p.p. is statistically significant, namely, that the applied exchange rate regimes had an impact on the difference in the mean values of the unemployment rate achieved in the fifteen-year period.

Table 7. Difference in unemployment rates between sample countries with fixed and sample countries with floating exchange rate regime

Overview of statistics:

\begin{tabular}{|l|l|l|l|l|l|}
\hline Variable & $\begin{array}{l}\text { Observa- } \\
\text { tions }\end{array}$ & Minimum & Maximum & Mean & Std. deviation \\
\hline Fixed regimes & 15 & 10.690 & 18.420 & 15.321 & 2.234 \\
\hline Fluctuating regimes & 15 & 7.031 & 15.355 & 11.034 & 3.438 \\
\hline
\end{tabular}

Results of a two-way Student's t-test for two independent samples:

\begin{tabular}{|l|l|}
\hline Difference & 4.287 \\
\hline $\mathrm{t}$ (Observed value) & 4.050 \\
\hline$|\mathrm{t}|$ (Critical value) & 2.048 \\
\hline $\mathrm{DF}$ & 28 \\
\hline $\begin{array}{l}\text { 95\% confidenceinterval on the difference between } \\
\text { the means: }\end{array}$ & $(2.119)$ to $(6.456)$ \\
\hline $\mathrm{p}$-value (Two-tailed) & 0.0004 \\
\hline alpha & 0.05 \\
\hline
\end{tabular}

Source: The result of data analysis using the Excel statistical tool - XLSTAT2016 


\section{CONCLUSION}

On the basis of the obtained results presented in the paper, the advantages of floating regimes in relation to fixed exchange rate regimes have not been proved on all key macroeconomic indicators of transition countries, grouped according to the level of development, in the analyzed period from 2000 to 2014. The research shows that the European transition countries in the analyzed period achieved successful economic growth measured by the average real GDP growth rates, but with statistically negligible differences. The research has not determined which exchange rate regime contributed to economic growth to a greater extent.

The research results of the effects of exchange rates regimes on the inflation rate reveal that in more developed European transition countries floating exchange rate regimes lead to price stability, and in the long run, to the levels ensured by fixed exchange rate regimes. Unlike more developed countries, the research has shown that fixed exchange rates lead to higher long-term price stability compared to floating exchange rate regimes in less developed European transition countries. The positive effect of floating regimes, in the long run, is particularly pronounced in employment. It has been determined that floating regimes, regardless of the level of the development of European transition countries, result in statistically significantly higher average employment rates than fixed exchange rates.

The research results, from the aspect of the internal balance, confirmed the justification of the application of floating regimes in more developed, but not in less developed European transition countries. On account of the research results, it can be concluded that the application of floating exchange rate regimes in more developed European transition countries, with statistically negligible differences in average rates of economic growth, is associated with a lower unemployment rate and price stability, which is approximately at the same level as ensured by fixed exchange rate regimes in the long run. At the same time, the research results suggest that the use of floating regimes in less developed European transition countries, in the long run, with virtually identical average rates of economic growth, is followed by a lower unemployment rate but a higher average inflation rate, compared to fixed exchange rate regimes. 


\section{REFERENCES}

1. Beker - Pucar, E. (2010). Upravljano fluktuiranje deviznog kursa u režimu inflacionog targetiranja u tranzicionim ekonomijama sa osvrtom na Srbiju. Neobjavljena doktorska disertacija. Subotica: Ekonomski fakultet. Univerzitet u Novom Sadu.

2. Bubula, A. and Ötker-Robe, I. (2002). The Evolution of Exchange Rate Regimes Since 1990: Evidence from De facto Policies. International Monetary Fund, WP/02/155.

3. Ćirović, M. (2000). Devizni kursevi. Beograd: Bridge Company

4. De Vita, G. and Kyaw, K. S. (2011). Does the Choice of Exchange Rate Regime Affect the Economic Growth of Developing Countries? The Journal of Developing Areas, Volume 45, Single Issue, Fall 2011, pp. 135-153.

5. Dornbusch, R. (1988). Real Exchange Rates and Macroeconomics: A Selective Survey. National Bureau Of Economic Research, Working Paper 2775.

6. Edwardsa, S. and Levy Yeyati, E. (2005). Flexible exchange rates as shock absorbers. European Economic Review, 49, pp. 2079-2105.

7. Fischer, S. and Sahay, R. (2000). The Transition Economies After Ten Years. National Bureau Of Economic Research, Working Paper 7664.

8. Frankel, J. A. (2003). Experience of and Lessons from Exchange Rate Regimes in Emerging Economies. National Bureau Of Economic Research, Working Paper 10032.

9. Ghosh, A., Gulde, A. M., Ostry, J. D. and Wolf, H. (1996). Does the Exchange Rate Regime Matter for Inflation and Growth?. Economic Issues 2, IMF.

10. Ghosh, A., Qureshi, M. S. and Tsangarides, C. (2011). Words vs. Deeds: What Really Matters? IMF, Working Paper, WP/11/112.

11. Habermeier, K., Kokenyne, A., Veyrune, R. and Anderson, H. (2009). Revised System for the Classification of Exchange Rate Arrangements. IMF, WP/09/211.

12. Ihnatov, I. and Căpraru, B. (2012). Exchange Rate Regimes and Economic Growth in Central and Eastern European Countries. Procedia Economics and Finance, 3, pp. 18-23.

13. Kovačević, R. (2002). Tranzicije zemalja centralne i istočne Evrope u tržišnu privredu. Privredna izgradnja, godina XLV: 3-4, str. 149-178.

14. Kovačević, R. (2011). Međunarodne finansije. Beograd: Centar za izdavačku djelatnost Ekonomskog fakulteta.

15. Krugman, R. P. i Obstfeld, M. (2009). Međunarodna ekonomija. Beograd: Datastatus

16. Levy-Yeyati, E. and Sturzenegger, F. (2000). Classifying Exchange Rate Regimes: Deeds vs. Words. Business School, Universidad Torcuato Di Tella. the LACEA Conference in Santiago de Chile. Preuzeto 04.06.2013. sa http://citeseerx.ist.psu.edu/viewdoc/ download?doi=10.1.1.32.6688\& rep=rep1 \&type $=p d f$.

17. Levy-Yeyati, E. and Sturzenegger, F. (2001). Exchange Rate Regimes and Economic Performance. IMF Staff Papers, Vol. 47, Special Issue, pp. 62-98.

18. International Monetary Fund (1997). Exchange Rate Arrangements and Economic Performance in Developing Countries, IV, pp. 78-97. Preuzeto 17.03.2016. sa https://www.imf.org/external/ pubs/ft/weo/weo1097/pdf/octweo04.pdf

19. International Monetary Fund. (2003). Classification of Exchange Rate Arrangements and Monetary Policy Frameworks, June. 30, 2003 [Zvanični podaci]. Dostupno na veb sajtu Medunarodnog monetarnog fonda: http://www.imf.org $>m f d>2003>$ eng

20. International Monetary Fund. (2008). De Facto Classification of Exchange Rate Regimes and Monetary Policy Frameworks, April, 2008. [Zvanični podaci]. Dostupno na veb sajtu Medunarodnog monetarnog fonda: http://www.imf.org $>$ mfd $>2008>$ eng

21. International Monetary Fund. (2014). Annual Report on Exchange Rate Arrangements and Exchange Restrictions, 2014. [Zvanični podaci]. Dostupno na veb sajtu Medunarodnog monetarnog fonda: http://www.imf.org > areaers > ar2014 
22. International Monetary Fund. (2016). World Economic Outlook Database, April 2016. [Zvanični podaci]. Dostupno na veb sajtu Medunarodnog monetarnogfonda: http://www.imf.org > 2016/01 $>$ weodata

23. Reinhart, C. M. and Rogoff, K. S. (2002). The Modern Historu of Exchange Rate Arrangements: a Reinterpretation. NBER, Working Paper 8963.

24. Rogoff, K., Husain, A. M., Mody, A., Brooks, R. and Oomes, N. (2003). Evolution and Performances of Exchange Rate Regimes. International Monetary Fund, WP/03/243.

25. Sosvilla-Riveroa, S. and Ramos-Herreraa, M. C. (2014). Exchange-rate regimes and economic growth: An empirical evaluation. DOCUMENTOS DE ECONOMÍA Y FINANZAS INTERNACIONALES, Working Papers on International Economics and Finance. Preuzeto 27.07.2017. sa http://www.aeefi.com/RePEc/pdf/defi14-01.pdf

26. Transition Report. (1999). EBRD, London. 